SYLWIA JASKULSKA

ORCID 0000-0002-3454-7894

BARBARA JANKOWIAK

ORCID 0000-0002-7660-2070

Uniwersytet im. Adama Mickiewicza

$w$ Poznaniu

\title{
POSTAWY NAUCZYCIELEK I NAUCZYCIELI WOBEC KSZTAŁCENIA NA ODLEGŁOŚĆ W CZASIE PANDEMII COVID-19
}

\begin{abstract}
AвSTRACt. Jaskulska Sylwia, Jankowiak Barbara, Postawy nauczycielek i nauczycieli wobec kształcenia na odległość w czasie pandemii COVID-19 [Teachers' Attitudes Toward Distance Education During the COVID-19 Outbreak]. Studia Edukacyjne nr 57, 2020, Poznań 2020, pp. 47-65. Adam Mickiewicz University Press. ISSN 1233-6688. DOI: 10.14746/se.2020.57.4
\end{abstract}

Despite the explosion of studies on social consequences of the COVID-19 outbreak, still little is known about the situation of teachers. This research report presents results of a study on teacher's attitudes toward distance education during the COVID-19 pandemic and their associations with selected characteristics related to the teacher's profession. The study consisted in answering questions in an online survey. Nearly eight hundred correctly completed surveys were collected. Multivariate analysis of variance (MANOVA) was applied to compare differences between the variables. The results show that the lowest averages on a Likert-type scale describe the cognitive component of attitudes, and the highest ones describe the behavioral component. Awareness of problems with the implementation of the curriculum and basic tasks of the school in the form of a distance education result in teachers' competence increase and taking specific action. Gender and seniority are not associated with the teachers' attitudes toward distance education. The type of school and the level of education were associated with attitudes towards distance education. Special schools teachers had the worst experience with distance education. The possible implications of these outcomes are discussed.

Key words: distance education, COVID-19, attitudes toward distance education, teachers

\section{Wprowadzenie}

Kształcenie na odległość zostało w Polsce wprowadzone Rozporządzeniem Ministra Edukacji Narodowej z 20 marca 2020 r. w sprawie szczegól- 
nych rozwiązań w okresie czasowego ograniczenia funkcjonowania jednostek systemu oświaty $\mathrm{w}$ związku $\mathrm{z}$ zapobieganiem, przeciwdziałaniem i zwalczaniem COVID-19 w marcu 2020 roku - dziewięć dni po zamknięciu z powodu epidemii COVID-19 szkół. W praktyce polegało ono na różnych formach synchronicznej i asynchronicznej pracy online. Zwykle uczniowie i uczennice oraz nauczyciele uczestniczyli w spotkaniach za pośrednictwem różnych, umożliwiających to platform, albo materiały, zadania i uczniowskie prace były przesyłane - również z wykorzystaniem różnych kanałów komunikacji ${ }^{1}$. Wraz z tą zmianą pojawił się szereg nowych wyzwań. Mnożące się pytania o możliwość realizacji $w$ tych warunkach programu nauczania, oceniania i egzaminowania uczniów, ale też budowania i podtrzymywania relacji wychowawczych, częściowe przejęcie zadań szkoły przez rodziny, nowe wymiary szkolnych nierówności wybrzmiewają $\mathrm{w}$ powstających $\mathrm{w}$ tym czasie tekstach $^{2}$ i znajdują odzwierciedlenie w prowadzonych badaniach ${ }^{3}$.

W prezentowanych w tym tekście badaniach wzięła udział grupa nauczycielek i nauczycieli o różnym stażu pracy, uczących na różnych etapach edukacji w różnych typach polskich szkół. Dostęp do sprzętu oraz innych technicznych udogodnień nauczycieli i uczniów nie były brane pod uwagę $\mathrm{w}$ tych badaniach, gdyż starano się wyjść poza obecne już w dostępnych analizach i debacie na temat kształcenia zdalnego problemy i przyjrzeć się sytuacji z innych perspektyw. Przedmiotem badania były nauczycielskie postawy wobec kształcenia na odległość ${ }^{4}$.

Badanie postaw jednostek umożliwia poznanie indywidualnego podejścia każdego człowieka, które jednak w określonych warunkach przekształcić się może w opinię publiczną, zaczynając determinować klimat społeczny, polityczny i kulturalny, który z kolei wpływa na życie poszczególnych jednostek $^{5}$. W związku z tym poznanie ludzkich postaw jest warunkiem wyjaśnienia i przewidywania działania nie tylko poszczególnych osób, ale również grup społecznych. W przypadku relacjonowanych tu badań postawy nauczycieli wobec kształcenia na odległość wydają się kluczowe dla możliwości re-

${ }^{1}$ Badanie edukacji zdalnej w czasie pandemii, Centrum Cyfrowe, https:/ / centrumcyfrowe.pl/ edukacja-zdalna/ [dostęp: 02.06.2020].

2 J. Pyżalski (red.), Edukacja w czasach pandemii wirusa COVID-19. Z dystansem o tym, co robimy obecnie jako nauczyciele, Warszawa 2020, https://zdalnie.edu-akcja.pl/; M. Turczyk, S. Jaskulska, Kształcenie na odległość a prawa dziecka - nowe wymiary szkolnej ekskluzji w czasach epidemii COVID-19, Edukacja Elementarna w Teorii i Praktyce, 2020 (w druku).

${ }^{3}$ A. Buchner, M. Majchrzak, M. Wierzbicka, Badanie edukacji zdalnej w czasie pandemii, https://centrumcyfrowe.pl/edukacja-zdalna/, [dostęp: 04.06.2020]; Jak wyglada nauczanie zdalne w naszych domach?' https:// portal.librus.pl/rodzina/artykuly/nauczanie-zdalne-jak-wyglada-w-naszych-domach-pobierz-raport? [dostęp: 04.06.2020].

${ }^{4}$ S. Jaskulska, B. Jankowiak, Kształcenie na odległość w Polsce w czasie pandemii COVID-19 https:/ / sites.google.com/view/ksztalcenie-pandemia-raport [dostęp: 04.06.2020].

${ }^{5}$ G. Bohner, M. Wanke, Postawy i zmiany postaw, Gdańsk 2004, s. 15. 
alizacji zadań szkoły, która z dnia na dzień zmieniła swój charakter z tradycyjnych relacji w klasie szkolnej na relacje i edukację zapośredniczone przez media. W badaniach pedagogicznych często sięga się po kategorię postawy, która staje się perspektywą oglądu nauczycielskiej rzeczywistości. Badane są postawy wobec codzienności szkoły, możliwości i kierunków jej zmiany, wobec uczniów i uczennic o specyficznych właściwościach (specjalne potrzeby edukacyjne, uczniowie sprawiający trudności wychowawcze), postawy wobec polityki oświatowej i tym podobne ${ }^{6}$.

Zgodnie z przyjętą definicją postawy uznano, że jest ona zawsze czyjaś i wobec czegoś i że składa się z trzech komponentów: poznawczego, rozumianego jako przekonania i wiedza o obiekcie postawy; behawioralnego, czyli mniej lub bardziej jednorodnego zespołu dyspozycji do zachowania się w określony sposób wobec obiektu postawy i emocjonalnego, który wyraża się w postaci dodatnich i ujemnych emocji towarzyszących wyobrażeniu przedmiotu postawy ${ }^{7}$. Postawa nauczycieli wobec kształcenia na odległość to przekonania na temat tej formy działania szkoły, stosunek emocjonalny do niej i działania, które podejmują, gotowość do ich podejmowania i ocena trudności związanych z wcielaniem tego kształcenia w życie oraz własnych kompetencji w tym zakresie. $W$ tekście zostaną zaprezentowane wyniki badań z dyskusją i zaznaczeniem ich ograniczeń, poprzedzone zarysem przyjętej metodologii.

\section{Metody}

\section{Cel}

Celem prowadzonych badań było: 1) zdiagnozowanie i opisanie postaw wobec kształcenia zdalnego w czasie pandemii COVID-19 w trzech komponentach (poznawczym, behawioralnym, emocjonalnym) i 2) eksploracja zależności pomiędzy wybranymi aspektami funkcjonowania zawodowego a postawami wobec kształcenia zdalnego w czasie pandemii COVID-19.

${ }^{6}$ Zob. M. Czajkowska, Postawy nauczycieli matematyki wobec zmian w edukacji, Społeczeństwo i Edukacja. Międzynarodowe Studia Humanistyczne, 2015, 3, s. 81-94; G. Kosiba, E. Madejski, Postawy nauczycieli wobec swej roli zawodowej w świetle wybranych koncepcji teoretycznych, Forum Oświatowe, 2014, 26(52), s. 101-112; J. Kossewska, Uwarunkowania postaw: nauczyciele i inne grupy zawodowe wobec integracji szkolnej dzieci niepetnosprawnych, Kraków 2000; P. Ratajczak, Postawy nauczycieli wobec niezdyscyplinowania uczniów, Studia Edukacyjne, 2015, 34, s. 167-176; M. Skura, Postawy nauczycieli szkoły specjalnej wobec osób z niepetnosprawnościa, Szkoła Specjalna, 2015, 1, s. 28-46.

7 M. Marody, Sens teoretyczny a sens empiryczny pojecia postawy analiza metodologiczna zasad doboru wskaźników w badaniach nad postawami, Warszawa 1976, s. 12-22; E.W. Aronson, T.D. Wilson, R.M. Akert, Psychologia społeczna. Serce i umyst, Poznań 1997. 


\section{Uczestnicy i uczestniczki}

Dobór do grupy badanej był celowy (nauczyciele/ki prowadzący zajęcia zdalne) i ochotniczy. W konsekwencji takiego doboru, a także ze względu na strukturę szkolnictwa i specyfikę demograficzną zatrudnienia w zawodzie nauczyciela w Polsce, w próbie przeważają:

- kobiety nad mężczyznami (677 kobiet i 105 mężczyzn);

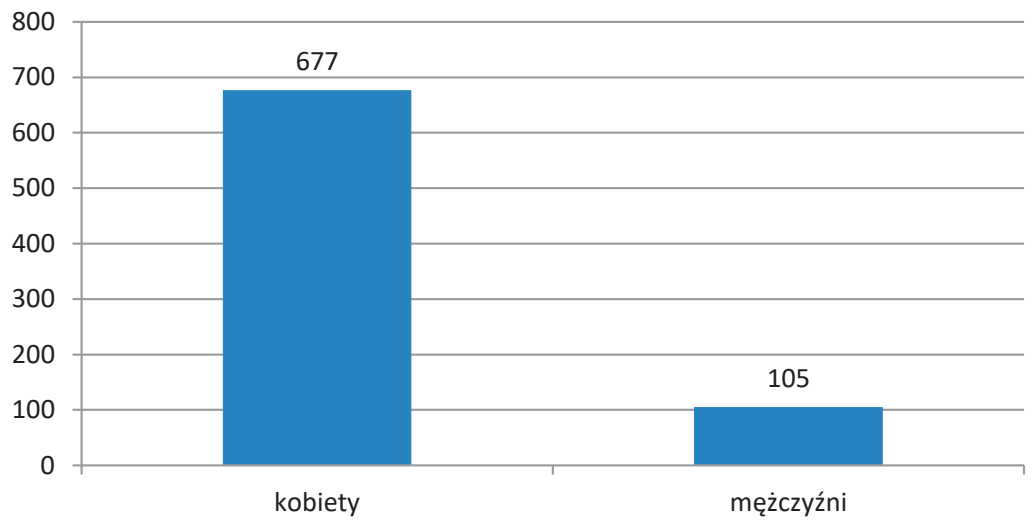

Ryc. 1. Zróżnicowanie badanej grupy ze względu na płeć

- osoby z najdłuższym stażem zawodowym: większość badanych osób pracowało w zawodzie powyżej 11 lat (585 osoby), 6-10 lat - 84 osoby, 2-5 lat - 78 osób i krócej niż 2 lata - 35 osób;

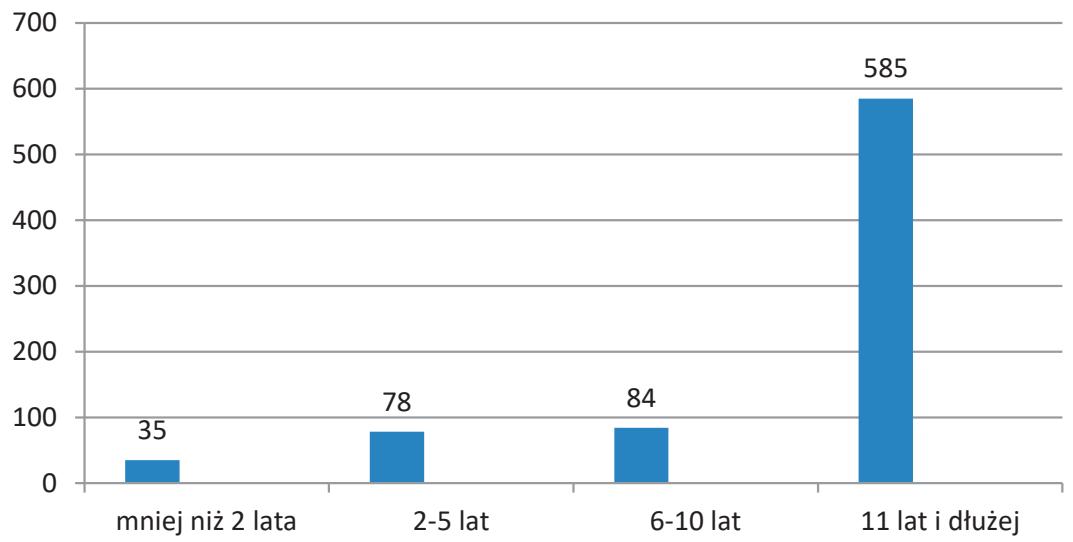

Ryc. 2. Zróżnicowanie badanej grupy ze względu na staż pracy w zawodzie nauczyciela 
- nauczycielki i nauczyciele zatrudnieni w szkołach podstawowych: większość z klas 4-8 (329 osób) i klas 1-3 (113 osób), a także liceów ogólnokształcących (118 osób), techników (43 osoby), szkół branżowych (6 osób). Aż 173 nauczycieli/lek pracowało w więcej niż jednym typie szkół;

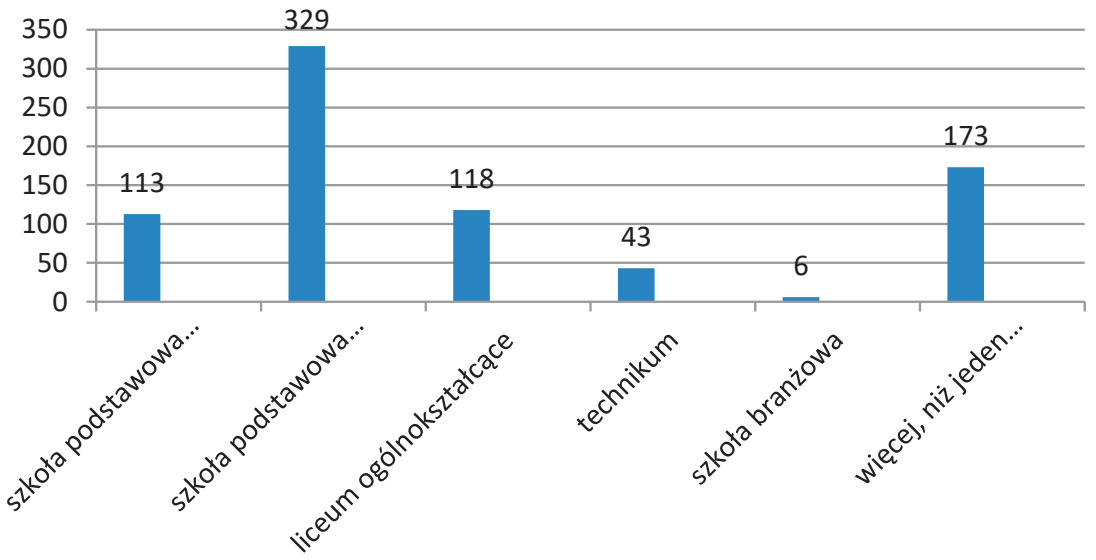

Ryc. 3. Zróżnicowanie badanej grupy ze względu na miejsce pracy (szczebel edukacyjny)

- nauczycielki i nauczyciele zatrudnieni w szkołach ogólnodostępnych: szkoły ogólnodostępne - 633 osób, ogólnodostępne z oddziałami specjalnymi/integracyjnymi - 71 osób, szkoły specjalne - 21 osób, integracyjne - 7 osób, 50 nauczycieli/lek pracowało w różnych rodzajach szkół;

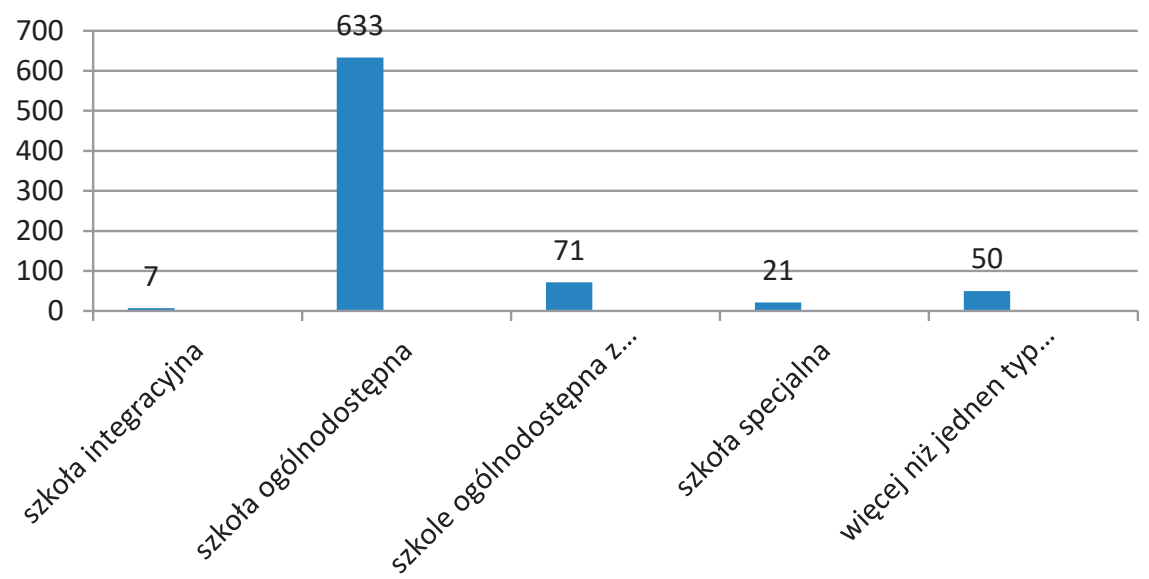

Ryc. 4. Zróżnicowanie badanej grupy ze względu na miejsce pracy (rodzaj szkoły) 
- nauczycielki i nauczyciele zatrudnieni w szkołach państwowych: szkoły państwowe - 630 osób, następnie prywatne - 50 osób, społeczne - 44 osoby. 58 nauczycieli pracowało $\mathrm{w}$ więcej niż jednym typie szkół.

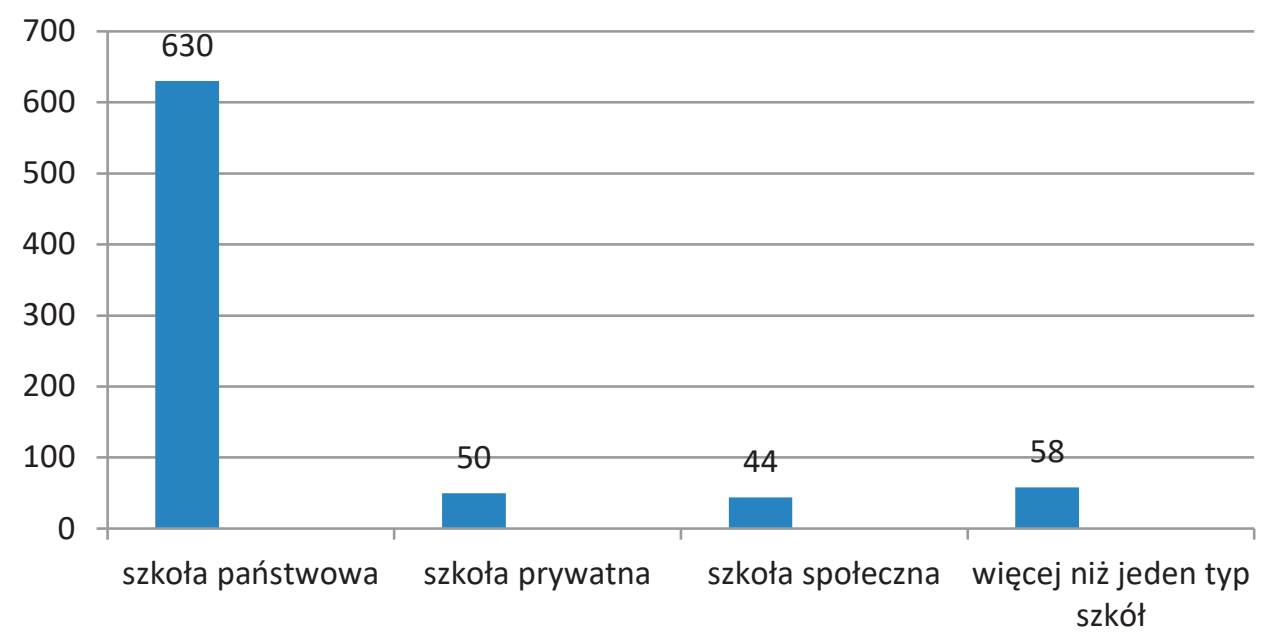

Ryc. 5. Zróżnicowanie badanej grupy ze względu na miejsce pracy (szczebel edukacyjny)

\section{Procedura}

Etap selekcyjny. Do badań kwalifikowani/ne byli/łe nauczyciele/ki prowadzący zajęcia zdalne. Ankieta dostępna była od 21 kwietnia do 18 maja 2020 roku, udostępniana na portalu społecznościowym Facebook, na stronach: Ja Nauczyciel'ka, Rok Relacji w Edukacji, Sylwia Jaskulska - Spotkania Edukacyjne i udostępniana przez użytkowników i użytkowniczki portalu, a także rozsyłana droga mailową do szkół.

Etap właściwy. Polegał na anonimowych badaniach kwestionariuszowych online. Kwestionariusz składał się z metryczki, części dotyczącej postaw wobec kształcenia zdalnego (12 pytań), skali prosperowania (8 pytań) i jednego pytania otwartego. Na początku kwestionariusza były umieszczone informacje, do kogo kierowane jest badanie (do czynnych zawodowo nauczycielek i nauczycieli pracujących w szkołach i prowadzących zajęcia zdalne), o celu badania, czasie jego trwania, prawach uczestników badań takich, jak: informacje o tym, że badanie jest anonimowe, dobrowolne i że w każdym momencie można się z niego wycofać bez podawania powodu, a wszystkie podane informacje są poufne oraz że drogą e-mailową można zadawać pytania dotyczące roli badanego z prowadzonym badaniu. Podany był także kontakt mailowy do prowadzących badanie. Na końcu zaproszenia do badania podana była informacja, że jeśli wyraża się zgodę na uczestnictwo, należy przejść do pytań właściwych.

Etap opracowania wyników. Polegał na statystycznym opracowaniu wyników (z użyciem pakietu statystycznego SPSS) oraz ich interpretacji. 


\section{Operacjonalizacja zmiennych}

Postawy nauczycieli wobec kształcenia zdalnego badane były z użyciem autorskiego kwestionariusza zawierającego 12 par stwierdzeń (po 4 pary do każdego z komponentów postawy - poznawczego, afektywnego, behawioralnego). Korzystając ze skali typu Likerta z poziomami od 1 do 7, respondenci wskazywali, w jakim stopniu się z tymi stwierdzeniami zgadzają.

Wybrane aspekty funkcjonowania zawodowego określane były w kilku aspektach: stażu pracy, miejsca zatrudnienia ze względu na etap kształcenia, miejsca zatrudnienia ze względu na rodzaj szkoły, miejsca zatrudnienia ze względu na typ szkoły.

\section{Analiza danych}

Do porównania rozkładów zmiennych i czynników je różnicujących zastosowano analizę wariancji dla wielu zmiennych (MANOVA). W sytuacji koniecznej uruchomiono test post-hoc Bonferroniego ( $p$-Bonferroniego). Przyjęty poziom istotności to $\alpha=0,05$.

\section{Wyniki}

\section{Postawy nauczycieli i nauczycielek wobec kształcenia zdalnego}

W zakresie każdego z trzech komponentów postaw badani mogli uzyskać od 4 do 28 punktów (4 pytania, 7-punktowa skala). W sumie postawy nauczycieli wobec kształcenia na odległość określono przyjmując za maksimum 84 a minimum 12 punktów. W opisie wyników tak dla postawy, jak i poszczególnych jej komponentów oraz obliczeniach statystycznych odnosimy się do średnich punktów (od 1 do 7 ).

\section{Poznawczy komponent postawy}

Aspekty kształcenia na odległość, które zostały wzięte pod uwagę odpowiadały trzem podstawowym funkcjom szkoły (kształcenie, wychowanie, opieka) ${ }^{8}$ oraz podnoszonego w debacie nad kształceniem na odległość problemu pogłębiania się różnic między uczniami9.

${ }^{8}$ Ustawa z 14 grudnia 2016 r. Prawo oświatowe (DzU 2020, poz. 374) oraz akty wykonawcze do ustawy; Rozporządzenie Ministra Edukacji Narodowej z 14 lutego 2017 r. w sprawie podstawy programowej wychowania przedszkolnego oraz podstawy programowej ksztatcenia ogólnego dla szkoty podstawowej, w tym dla uczniów z niepetnosprawnościa intelektualna w stopniu umiarkowanym lub znacznym, kształcenia ogólnego dla branżowej szkoły I stopnia, kształcenia ogólnego dla szkoły specjalnej przysposabiajacej do pracy oraz ksztatcenia ogólnego dla szkoty policealnej, DzU z 2017 r., poz. 356.

${ }^{9}$ Ponadto, brakujący tekst 9 przypisu do art. Jaskulska Sylwia, Jankowiak Barbara: P. Plichta, Różne konteksty nierówności cyfrowych a wyzwania dla zdalnej edukacji - propozycje rozwiązań, [w:] Edukacja w czasach pandemii wirusa COVID-19. Z dystansem o tym, co robimy obecnie jako nauczyciele, red. J. Pyżalski, Warszawa 2020, https://zdalnie.edu-akcja.pl/; M. Turczyk, S. Jaskulska, Kształcenie na odległość a prawa dziecka - nowe wymiary szkolnej ekskluzji w czasach epidemii COVID-19, Edukacja Elementarna w Teorii i Praktyce, 2020 (w druku). 
Badani zaznaczali odpowiedzi na 7-stopniowej skali, odnosząc się do stwierdzeń, że kształcenie na odległość: 1) pozwala z powodzeniem realizować podstawę programową - uniemożliwia realizację z powodzeniem podstawy programowej; 2) pozwala z powodzeniem realizować działalność wychowawczą szkoły - uniemożliwia realizację z powodzeniem działalności wychowawczej szkoły; 3) pozwala z powodzeniem realizować działalność opiekuńczą szkoły - uniemożliwia realizację z powodzeniem działalności opiekuńczej szkoły; 4) wyrównuje różnice między uczniami - pogłębia różnice między uczniami. Procentowy rozkład odpowiedzi przedstawiony został w tabeli 1.

Tabela 1

Komponent poznawczy postawy - procentowy rozkład odpowiedzi

\begin{tabular}{|c|c|c|c|c|c|}
\hline \multicolumn{2}{|c|}{$\begin{array}{l}\text { Kształ- } \\
\text { cenie } \\
\text { na od- } \\
\text { ległość }\end{array}$} & $\begin{array}{c}\text { (1) uniemożli- } \\
\text { wia realizację } \\
\text { z powodzeniem } \\
\text { podstawy pro- } \\
\text { gramowej/ } \\
\text { (7) pozwala z po- } \\
\text { wodzeniem reali- } \\
\text { zować podstawę } \\
\text { programową }\end{array}$ & $\begin{array}{c}\text { (1) uniemożli- } \\
\text { wia realizację } \\
\text { z powodzeniem } \\
\text { działalności } \\
\text { wychowawczej } \\
\text { szkoły/ } \\
\text { (7) pozwala } \\
\text { z powodzeniem } \\
\text { realizować dzia- } \\
\text { łalność wycho- } \\
\text { wawczą szkoły }\end{array}$ & $\begin{array}{l}\text { (1) uniemożli- } \\
\text { wia realizację } \\
\text { z powodzeniem } \\
\text { działalności opie- } \\
\text { kuńczej szkoły/ } \\
\text { (7) pozwala } \\
\text { z powodzeniem } \\
\text { realizować dzia- } \\
\text { łalność opiekuń- } \\
\text { czą szkoły }\end{array}$ & $\begin{array}{l}\text { (1) pogłębia } \\
\text { różnice między } \\
\text { uczniami/ } \\
\text { (7) wyrównuje } \\
\text { różnice między } \\
\text { uczniami }\end{array}$ \\
\hline \multirow{2}{*}{1} & $\mathrm{~N}$ & 27 & 80 & 258 & 186 \\
\hline & $\%$ & 3 & 10 & 33 & 24 \\
\hline \multirow{2}{*}{2} & $\mathrm{~N}$ & 88 & 178 & 222 & 178 \\
\hline & $\%$ & 11 & 23 & 28 & 23 \\
\hline \multirow{2}{*}{3} & $\mathrm{~N}$ & 117 & 142 & 68 & 106 \\
\hline & $\%$ & 15 & 18 & 9 & 14 \\
\hline \multirow{2}{*}{4} & $\mathrm{~N}$ & 205 & 149 & 67 & 170 \\
\hline & $\%$ & 26 & 19 & 9 & 22 \\
\hline \multirow{2}{*}{5} & $\mathrm{~N}$ & 134 & 105 & 59 & 61 \\
\hline & $\%$ & 17 & 13 & 8 & 8 \\
\hline \multirow{2}{*}{6} & $\mathrm{~N}$ & 128 & 98 & 58 & 42 \\
\hline & $\%$ & 16 & 13 & 7 & 5 \\
\hline \multirow{2}{*}{7} & $\mathrm{~N}$ & 83 & 30 & 50 & 39 \\
\hline & $\%$ & 11 & 4 & 6 & 5 \\
\hline
\end{tabular}




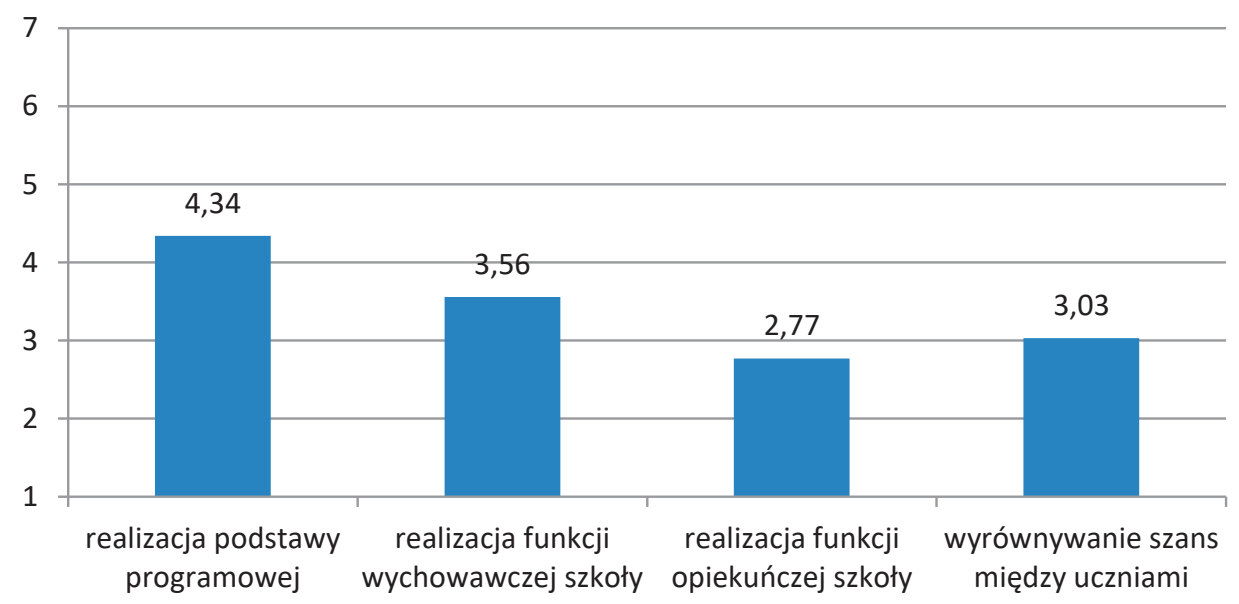

Ryc. 6. Komponent poznawczy postawy (średnie)

Ogólna średnia dla komponentu poznawczego postawy to 3,42 (min. 1, max. 7). Nauczycielki i nauczyciele są przekonani w wyższym stopniu, że można realizować w czasie kształcenia zdalnego podstawę programową, niż wychowawczą, a szczególnie opiekuńczą funkcję szkoły. Nauczyciele i nauczycielki wyrazili także opinie, że nauczanie zdalne raczej pogłębia różnice między uczniami i uczennicami, niż je wyrównuje.

\section{Behawioralny komponent postawy}

Komponent behawioralny tworzą deklaracje na temat działań podejmowanych przed pandemią COVID-19, przewidywań w odniesieniu do wykorzystania nabywanych $\mathrm{w}$ tym czasie umiejętności $\mathrm{w}$ przyszłości, ocena wzrostu własnych kompetencji zawodowych i doświadczanych w realizacji kształcenia zdalnego trudności. Stwierdzenie, do których odnosili się badani, to kształcenie na odległość: 1) nie przysparza mi trudności - przysparza mi trudności; 2) pozwala mi rozwijać kompetencje zawodowe - ogranicza rozwój moich kompetencji zawodowych;3) nie jest mi obce - wdrażałem/am już jego elementy w mojej pracy - jest mi obce - nigdy nie wdrażałem/am jego elementów w mojej pracy; 4) na pewno wykorzystam je w pracy w przyszłości - na pewno nie wykorzystam go w pracy w przyszłości, jeśli nie będzie znów takiej konieczności.

Ogólna średnia dla tego komponentu to 4,63 (min. 1, max. 7). Nauczyciele, choć nie mieli wielu doświadczeń z kształceniem zdalnym przed pandemią COVID-19, deklarują chęć wykorzystania nowych umiejętności w przyszłości oraz mają poczucie rozwoju własnych kompetencji zawodowych. Ponadto, kształcenie na odległość raczej nie przysparza im trudności. 
Tabela 2

Komponent behawioralny postawy - procentowy rozkład odpowiedzi

\begin{tabular}{|c|c|c|c|c|c|}
\hline & $\begin{array}{l}\text { ał- } \\
\text { ie } \\
\text { dle- } \\
\text { ść }\end{array}$ & $\begin{array}{l}\text { (1) przysparza } \\
\text { mi trudności/ } \\
\text { (7) nie przy- } \\
\text { sparza mi trud- } \\
\text { ności }\end{array}$ & $\begin{array}{l}\text { (1) ogranicza } \\
\text { rozwój moich } \\
\text { kompetencji } \\
\text { zawodowych/ } \\
\text { (7) pozwala mi } \\
\text { rozwijać } \\
\text { kompetencje } \\
\text { zawodowe }\end{array}$ & $\begin{array}{c}\text { (1) jest mi obce } \\
\text { - nigdy nie } \\
\text { wdrażałem/am } \\
\text { jego elementów } \\
\text { w mojej pracy/ } \\
\text { (7) nie jest mi } \\
\text { obce - wdraża- } \\
\text { łem/am już jego } \\
\text { elementy w mojej } \\
\text { pracy }\end{array}$ & $\begin{array}{l}\text { (1) na pewno nie } \\
\text { wykorzystam go } \\
\text { w pracy w przy- } \\
\text { szłości, jeśli } \\
\text { nie będzie znów } \\
\text { takiej konieczności/ } \\
\text { (7) na pewno wyko- } \\
\text { rzystam je w pracy } \\
\text { w przyszłości }\end{array}$ \\
\hline 1 & $\mathrm{~N}$ & 54 & 28 & 200 & 30 \\
\hline 1 & $\%$ & 7 & 4 & 26 & 4 \\
\hline 2 & $\mathrm{~N}$ & 81 & 44 & 119 & 42 \\
\hline 2 & $\%$ & 10 & 6 & 15 & 5 \\
\hline 3 & $\mathrm{~N}$ & 130 & 43 & 73 & 57 \\
\hline 3 & $\%$ & 17 & 5 & 9 & 7 \\
\hline 4 & $\mathrm{~N}$ & 123 & 159 & 107 & 120 \\
\hline 4 & $\%$ & 16 & 20 & 14 & 15 \\
\hline 5 & $\mathrm{~N}$ & 84 & 108 & 86 & 123 \\
\hline 0 & $\%$ & 11 & 14 & 11 & 16 \\
\hline & $\mathrm{N}$ & 157 & 180 & 86 & 158 \\
\hline 6 & $\%$ & 20 & 23 & 11 & 20 \\
\hline 7 & $\mathrm{~N}$ & 153 & 220 & 111 & 252 \\
\hline 7 & $\%$ & 20 & 28 & 14 & 32 \\
\hline
\end{tabular}

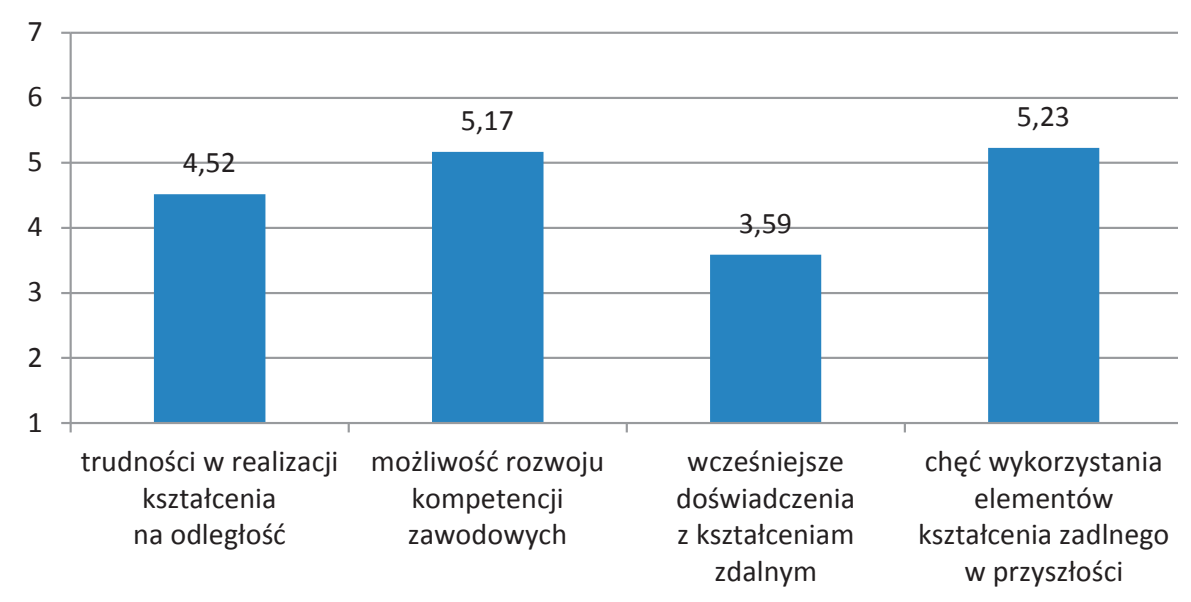

Ryc. 7. Komponent behawioralny postawy (średnie) 


\section{Emocjonalny komponent postawy}

Ostatnim elementem postawy jest stosunek emocjonalny badanych osób do kształcenia na odległość. Uwzględniono emocje w relacjach z najważniejszymi podmiotami - uczniami, ich rodzicami, a także poczucie wsparcia ze strony dyrekcji. Stwierdzenia, do których odnosili się nauczyciele i nauczycielki, były takie, że kształcenie na odległość: 1) wyzwala we mnie negatywne emocje - wyzwala we mnie pozytywne emocje; 2) sprawia, że odczuwam negatywne emocje w relacjach z uczniami i uczennicami - sprawia, że odczuwam pozytywne emocje w relacjach z uczniami i uczennicami; 3) sprawia, że odczuwam negatywne emocje $\mathrm{w}$ relacjach $\mathrm{z}$ rodzicami uczniów i uczennic - sprawia, że odczuwam pozytywne emocje w relacjach z rodzicami uczniów i uczennic; 4) sprawia, że odczuwam brak wsparcia ze strony dyrekcji szkoły - sprawia, że odczuwam wsparcie ze strony dyrekcji szkoły.

Tabela 3

Komponent emocjonalny postawy - procentowy rozkład odpowiedzi

\begin{tabular}{|c|c|c|c|c|c|}
\hline \multicolumn{2}{|c|}{$\begin{array}{l}\text { Kształ- } \\
\text { cenie } \\
\text { na odle- } \\
\text { głość }\end{array}$} & $\begin{array}{l}\text { (1) wyzwala we } \\
\text { mnie negatywne } \\
\text { emocje/ } \\
\text { (7) wyzwala we } \\
\text { mnie pozytywne } \\
\text { emocje }\end{array}$ & $\begin{array}{c}\text { (1) sprawia, } \\
\text { że odczuwam } \\
\text { negatywne } \\
\text { emocje w rela- } \\
\text { cjach z uczniami } \\
\text { i uczennicami/ } \\
\text { (7) sprawia, } \\
\text { że odczuwam } \\
\text { pozytywne } \\
\text { emocje w rela- } \\
\text { cjach z uczniami } \\
\text { i uczennicami }\end{array}$ & $\begin{array}{l}\text { (1) sprawia, że } \\
\text { odczuwam ne- } \\
\text { gatywne emocje } \\
\text { w relacjach z ro- } \\
\text { dzicami uczniów } \\
\text { i uczennic/ } \\
\text { (7) sprawia, że } \\
\text { odczuwam po- } \\
\text { zytywne emocje } \\
\text { w relacjach z ro- } \\
\text { dzicami uczniów } \\
\text { i uczennic }\end{array}$ & $\begin{array}{c}\text { (1) sprawia, że } \\
\text { odczuwam brak } \\
\text { wsparcia ze } \\
\text { strony dyrekcji } \\
\text { szkoły/ } \\
\text { (7) sprawia, } \\
\text { że odczuwam } \\
\text { wsparcie ze } \\
\text { strony dyrekcji } \\
\text { szkoły }\end{array}$ \\
\hline \multirow{2}{*}{1} & $\mathrm{~N}$ & 56 & 24 & 26 & 97 \\
\hline & $\%$ & 7 & 3 & 3 & 12 \\
\hline \multirow{2}{*}{2} & $\mathrm{~N}$ & 97 & 37 & 67 & 85 \\
\hline & $\%$ & 12 & 5 & 9 & 11 \\
\hline \multirow{2}{*}{3} & $\mathrm{~N}$ & 99 & 56 & 80 & 74 \\
\hline & $\%$ & 13 & 7 & 10 & 9 \\
\hline \multirow{2}{*}{4} & $\mathrm{~N}$ & 232 & 216 & 282 & 150 \\
\hline & $\%$ & 30 & 28 & 36 & 19 \\
\hline \multirow{2}{*}{5} & $\mathrm{~N}$ & 109 & 126 & 117 & 100 \\
\hline & $\%$ & 14 & 16 & 15 & 13 \\
\hline \multirow{2}{*}{6} & $\mathrm{~N}$ & 97 & 187 & 133 & 128 \\
\hline & $\%$ & 12 & 24 & 17 & 16 \\
\hline \multirow{2}{*}{7} & $\mathrm{~N}$ & 92 & 136 & 77 & 148 \\
\hline & $\%$ & 12 & 17 & 10 & 19 \\
\hline
\end{tabular}




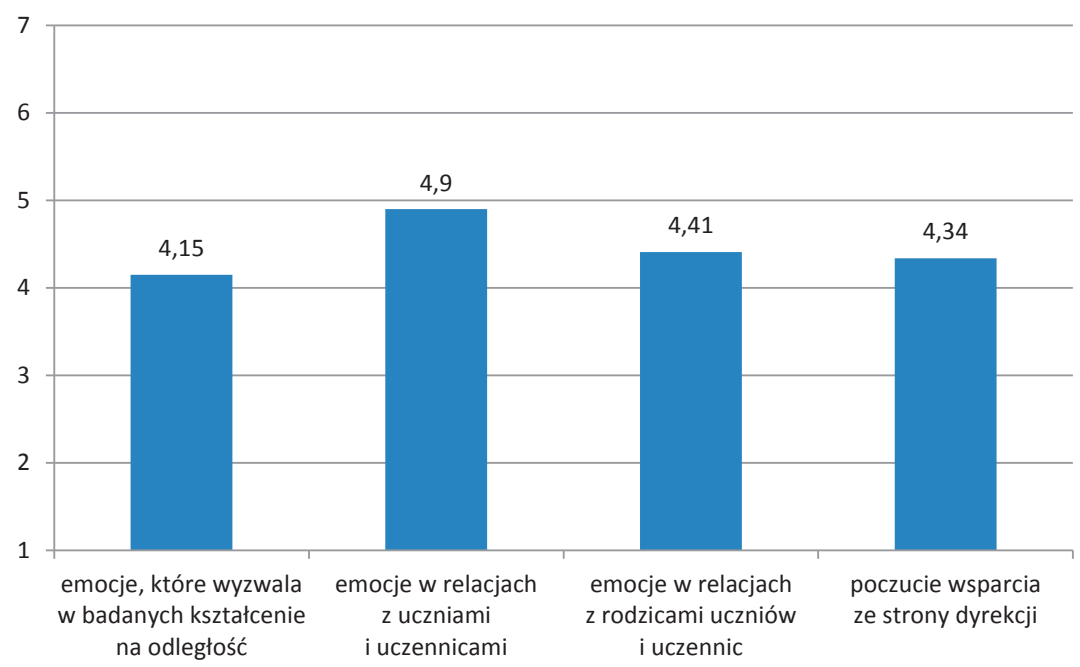

Ryc. 8. Ukształtowanie komponentu emocjonalnego postawy

Średnia dla całego komponentu to 4,45 (min. 1, max. 7). Nauczycielki i nauczyciele odczuwają raczej pozytywne niż negatywne emocje wobec różnych aspektów kształcenia na odległość. Najlepiej respondenci i respondentki ocenili emocje, których doświadczają w relacjach z uczniami.

\section{Struktura postawy wobec kształcenia na odległość}

Ryc. 9. Struktura postawy

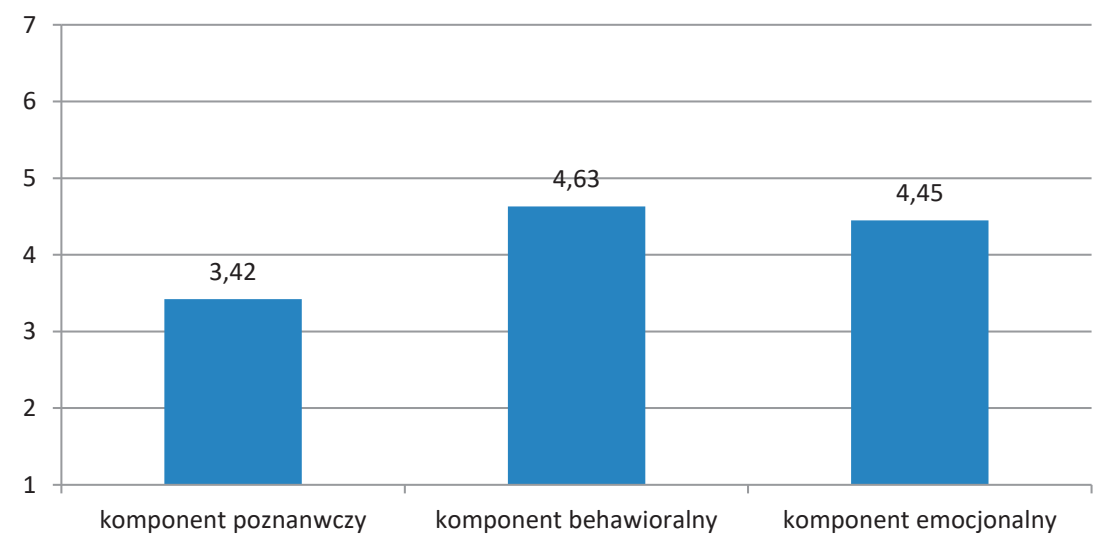

Ogólna średnia 4,17 punktów (min. 1, max. 7) każe wnioskować, że postawa nauczycielek i nauczycieli wobec kształcenia na odległość jest przeciętna. 
Porównanie średnich dla każdego z komponentów wzbogaca ten wniosek o inne - nauczycielki i nauczyciele raczej negatywnie widzą możliwość realizacji w ten sposób podstawowych zadań szkoły i wyrównywania szans między uczniami, nie są więc przekonani do kształcenia na odległość. Jednocześnie nauczyciele i nauczycielki podjęli działania, z których są zadowoleni i odczuwają raczej pozytywne emocje wobec różnych aspektów edukacji na odległość (szczególnie wobec kontaktów ze swoimi uczniami i uczennicami).

\section{Wybrane aspekty funkcjonowania zawodowego a postawy wobec kształcenia zdalnego}

W dalszej kolejności poddano analizie związek pomiędzy postawami wobec kształcenia na odległość a wybranymi aspektami funkcjonowania zawodowego nauczycieli i nauczycielek takimi, jak staż pracy czy miejsce zatrudnienia. Uzyskano także wyniki wskazujące na różnice $\mathrm{w}$ postawach między kobietami a mężczyznami $(\mathrm{F}=4,738, \mathrm{p}<0,05)$. Nauczyciele mają statystycznie istotnie wyższą ogólną średnią punktów $(4,22)$, niż nauczycielki $(4,180)$.

\section{Staż pracy}

Zmienna ta nie różnicuje żadnego z komponentów postaw.

\section{Miejsce zatrudnienia ze względu na etap kształcenia}

Zaobserwowano efekt główny etapu kształcenia, na którym pracuje nauczyciel na emocje odczuwane $\mathrm{w}$ relacjach $\mathrm{z}$ rodzicami uczniów i uczennic $(\mathrm{F}=2,651, \mathrm{p}<0,05) \mathrm{w}$ tym sensie, że nauczycielki i nauczyciele pracujący w szkole podstawowej w klasach I-III czują, że kształcenie na odległość wyzwala w nich pozytywne emocje $\mathrm{w}$ tej relacji statystycznie istotnie częściej, niż nauczyciele szkoły podstawowej (klasy IV-VIII) (różnica średnich $=0,91$, p-Bonferroniego < 0,05) i liceum (różnica średnich =1,08, p-Bonferroniego < 0,05).

\section{Miejsce zatrudnienia ze względu na rodzaj szkoły}

Okazało się, że postawy nauczycieli i nauczycielek wobec kształcenia na odległość najbardziej różnicuje rodzaj szkoły, w której pracują. Najniższe średnie $\mathrm{w}$ wielu zakresach opisują postawy nauczycielek i nauczycieli zatrudnionych w szkołach specjalnych.

A zatem, efekt rodzaju szkoły zaobserwowano dla elementów postawy: przekonania, że kształcenie na odległość sprzyja wyrównywaniu szans uczniów ( $\mathrm{F}=2,438, \mathrm{p}<0,05)$, poczucia zakresu doświadczanych przez nauczycielki i nauczycieli trudności $(\mathrm{F}=3,716, \mathrm{p}<0,01)$, przekonania, na ile zwiększa się w sytuacji nauczania na odległość zakres posiadanych przez na- 
uczycieli kompetencji zawodowych $(\mathrm{F}=2,533, \mathrm{p}<0,05)$ i przekonania, na ile nowe kompetencje wykorzysta się w przyszłości $(F=3,512$, p < 0,01), a także ogólnej średniej postawy $(\mathrm{F}=4,584, \mathrm{p}<0,01)$ i średnich punktów komponentu poznawczego $(\mathrm{F}=3,086, \mathrm{p}<0,05)$, behawioralnego $(\mathrm{F}=3,888, \mathrm{p}<0,01)$ i emocjonalnego $(\mathrm{F}=2,806, \mathrm{p}<0.05)$.

Deklarując swoje przekonania na temat możliwości wyrównywania szans uczniów w kształceniu na odległość, nauczycielki i nauczyciele ze szkół specjalnych uzyskali średnią punktów 1,88 na 7 możliwych, podczas gdy z innych rodzajów szkół przynajmniej o jeden punkt więcej, a pracujący w kilku rodzajach szkół średnio aż 3,51 punktów ( $p$-Bonferroniego $<0,05$ ).

Statystycznie istotnie różnią się też średnie opisujące trudności, których doświadczają nauczycielki i nauczyciele szkół specjalnych $(2,83)$ oraz innych rodzajów szkół: integracyjnych $(6,25$; różnica średnich 3,41, p-Bonferroniego < 0,05); ogólnodostępnych (4,81; różnica średnich 1,98, p-Bonferroniego < 0,005); więcej, niż jednego rodzaju szkół (5,02; różnica średnich 2,18, p-Bonferroniego < 0,005). W znacznie mniejszym stopniu ta grupa dostrzega też możliwość wykorzystania nowych kompetencji w przyszłości. Średnia osób zatrudnionych w szkołach specjalnych to 3,82, podczas gdy: w szkołach ogólnodostępnych 5,55 (różnica średnich 1,73, p-Bonferroniego < 0,005), w więcej niż jednym typie szkół 5,47 (różnica średnich 1,66, p-Bonferroniego <0,05). Różnią się też wyniki dla szkół ogólnodostępnych $(5,55)$ i ogólnodostępnych z oddziałami integracyjnymi/specjalnymi $(4,81$; różnica średnich 1,13 , p-Bonferoniego $<0,01)$.

Ponieważ zaobserwowano wiele istotnych statystycznie zależności między rodzajem szkoły a średnimi dla poszczególnych komponentów postawy, wszystkie analizowane średnie zostały zebrane w tabeli 4 .

Komponenty postawy a rodzaj szkoły

Tabela 4

\begin{tabular}{|l|c|c|c|c|}
\hline $\begin{array}{c}\text { Miejsce zatrudnie- } \\
\text { nia nauczyciela/ } \\
\text { nauczycielki }\end{array}$ & $\begin{array}{c}\text { Poznawczy } \\
\text { komponent } \\
\text { postawy }\end{array}$ & $\begin{array}{c}\text { Behawioralny } \\
\text { komponent } \\
\text { postawy }\end{array}$ & $\begin{array}{c}\text { Emocjonalny } \\
\text { komponent } \\
\text { postawy }\end{array}$ & $\begin{array}{c}\text { Postawa } \\
\text { suma }\end{array}$ \\
\hline $\begin{array}{l}\text { Szkoła integra- } \\
\text { cyjna }\end{array}$ & 4,04 & 5,59 & 4,94 & 4,86 \\
\hline $\begin{array}{l}\text { Szkoła ogólnodo- } \\
\text { stępna }\end{array}$ & 3,41 & 4,77 & 4,59 & 4,26 \\
\hline $\begin{array}{l}\text { Szkoła ogólnodo- } \\
\text { stępna z oddzia- } \\
\begin{array}{l}\text { łami integracyjny- } \\
\text { mi/specjalnymi }\end{array}\end{array}$ & 3,26 & 4,12 & 3,99 & 3,79 \\
\hline Szkoła specjalna & 2,40 & 3,56 & 4,10 & 3,36 \\
\hline $\begin{array}{l}\text { Więcej niż jeden } \\
\text { typ szkół }\end{array}$ & 3,63 & 5,06 & 4,75 & 4,48 \\
\hline
\end{tabular}


Średnie osób pracujących w szkołach specjalnych są najniższe, istotnie statystycznie różnią się:

- w zakresie komponentu poznawczego średnie osób pracujących w szkołach specjalnych i więcej niż jednym typie szkoły (różnica średnich 1,22, p-Bonferroniego < 0,05);

- w zakresie komponentu behawioralnego średnie osób pracujących w szkołach specjalnych i integracyjnych (różnica średnich 2,03, p-Bonferroniego $<0,05$ ); specjalnych i ogólnodostępnych (różnica średnich 1,20, p-Bonferroniego < 0,05); specjalnych i więcej niż jednym typie szkół (różnica średnich 1,50, p-Bonferroniego < 0,01); szkołach z oddziałami specjalnymi/integracyjnymi i więcej niż jednym typie szkół (różnica średnich 0,93, p-Bonferroniego < 0,05);

- w zakresie ogólnej średniej postawy średnie osób pracujących w szkołach specjalnych i integracyjnych (różnica średnich 1,50, p-Bonferroniego $<0,05$ ); specjalnych i ogólnodostępnych (różnica średnich 0,90, p-Bonferroniego < 0,05); szkołach z oddziałami specjalnymi/integracyjnymi i więcej niż jednym typie szkół (różnica średnich 0,69, p-Bonferoniego < 0,05); specjalnych i więcej niż jednym typie szkół (różnica średnich 1,12, p-Bonferroniego < 0,005).

\section{Miejsce zatrudnienia ze względu na typ szkoły}

Zaobserwowano efekt główny typu szkoły na przekonania nauczycieli i nauczycielek na temat możliwości realizacji w czasie nauczania na odległość podstawy programowej $(\mathrm{F}=3,94, \mathrm{p}<0,01)$ - statystycznie istotnie różnią się średnie nauczycieli zatrudnionych $\mathrm{w}$ szkołach państwowych $(4,02)$ i prywatnych $(5,03)$ (różnica średnich 1,01, p-Bonferroniego $<0,01$ ) i na odczuwane wsparcie ze strony dyrekcji $(\mathrm{F}=4,38, p<0,01)$ - statystycznie istotnie różnią się średnie nauczycieli zatrudnionych w szkołach państwowych $(3,90)$ i społecznych $(5,50)$ (różnica średnich 1,60, p-Bonferroniego < 0,005).

\section{Dyskusja}

Nauczyciele i nauczycielki dostrzegają problemy, które wiążą się z realizacją funkcji szkoły w zmienionych przez przejście na kształcenie zdalne warunkach, co znajduje potwierdzenie w niskich wynikach komponentu poznawczego postawy. Stan ten można uzasadniać w dwójnasób. Po pierwsze, odnosząc się do wyników dla poszczególnych elementów komponentu poznawczego. O ile badane osoby dostrzegają możliwość realizacji w tych warunkach podstawy programowej, o tyle co do realizacji działań wychowawczych i opiekuńczych mają mniejsze przekonanie - a nawet bardzo niskie. Średnia dla stwierdzenia: 1) uniemożliwia realizację z powodzeniem działalności opiekuńczej szkoły - (7) pozwala z powodzeniem realizować dziatalność opiekuńcza 
szkoły jest najniższą ze wszystkich w całym badaniu. Niskie wyniki w obszarze komponentu poznawczego mogą być wskaźnikiem tego, że nauczyciele dostrzegają problem.

Warto w tym miejscu dodać, że wśród wniosków z badań Edukacja zdalna $w$ czasie pandemii prowadzonych przez Centrum Cyfrowe znalazł się ten, że

nauczyciele zwracają uwagę na fakt, że brak empatii i elastyczności przejawiający się stawianiem na pierwszym miejscu podstawy programowej, a nie zdrowia psychicznego dzieci i rodziców, a także ich samych jest poważnym błędem ${ }^{10}$.

Nastawienie ustawodawców na realizację dydaktycznej funkcji szkoły i niedowartościowanie pozostałych jej zadań przekłada się na codzienność kształcenia na odległość i może mieć długofalowe konsekwencje. Problem ograniczenia wychowawczo-opiekuńczej funkcji szkoły na rzecz funkcji dydaktycznej nie jest $\mathrm{w}$ odniesieniu do edukacji szkolnej zagadnieniem nowym ${ }^{11}$, ale $\mathrm{w}$ czasie kryzysu potęguje trudną sytuację, w której znajdują się niektórzy uczniowie, których rodziny nie zapewniają bezpieczeństwa i opieki.

Drugi kierunek interpretacji zdiagnozowanego stanu ma źródło w sposobie rozumienia, czym jest postawa i jak się ona kształtuje. Respondenci i respondentki uzyskali wysokie wyniki w komponencie behawioralnym postawy (szczególnie w aspekcie możliwości wykorzystania kształcenia online $\mathrm{w}$ pracy w przyszłości oraz rozwoju własnych kompetencji zawodowych) i dość wysokie w komponencie emocjonalnym (szczególnie ze względu na pozytywne uczucia, jakich doznają w kontaktach z uczniami i uczennicami). Uzyskane wyniki wydają się zrozumiałe w zaistniałej sytuacji, w której nauczycielki i nauczyciele musieli zaangażować się w nową formę edukacji bez względu na wcześniejsze doświadczenia, własne poglądy na ten temat i posiadane kompetencje. Nie dziwi więc, że w komponencie poznawczym uzyskują niższe wyniki, niż w pozostałych. Jednocześnie respondenci i respondentki podjęli działania, które dały im szansę rozwinąć kompetencje zawodowe, uzyskać kontrolę nad trudną sytuacją zawodową i w związku z tym doświadczyć pozytywnych emocji. Nauczyciele i nauczycielki dobrze oceniają własną aktywność, stąd wysokie wyniki komponentu behawioralnego i pozytywne odczucia (komponent emocjonalny). Wobec takich wyników powstaje pytanie, czy przedłużająca się sytuacja, w której nauczyciele będą podejmować

${ }^{10}$ Badanie edukacji zdalnej w czasie pandemii, Centrum Cyfrowe, https:/ / centrumcyfrowe.pl/ edukacja-zdalna/, s. 37, [dostęp: 04.06.2020].

11 S. Jaskulska, Ocenianie zachowania uczniów na stopień. Szkolna obsesja porządku w świetle matematycznej teorii chaosu, Podstawy Edukacji, 2015, 8, s. 187-197; R. Nawrocki, Edukacja jako pole gry, [w:] Twierdza. Szkoła w metaforze militarnej. Co w zamian?, red. M. Dudzikowa, S. Jaskulska, Warszawa 2016; M. Żytko, Edukacja w ramionach standaryzacji - czy autonomia jest jeszcze możliwa? Czas Kultury, 2020, 1. 
kształcenie na odległość nie doprowadzi do modyfikacji ich przekonań na jego temat, gdyż po pierwsze wdrożą nowe rozwiązania w swojej pracy, a po drugie - ponieważ $w$ pewnych okolicznościach to podejmowanie działań może kształtować postawy. O postawie opartej na komponencie behawioralnym mówimy wtedy, gdy początkowa postawa jest niejasna oraz wieloznaczna i jednostka wnioskuje o niej na podstawie własnego zachowania ${ }^{12}$. Nauczycielki i nauczyciele $w$ większości nie podejmowali wcześniej nauczania zdalnego, więc mogli nie mieć ukształtowanych poglądów na jego temat i teraz podejmując działania edukacyjne na odległość, zaczynają kształtować własne przekonania na jego temat. Aby przekonania nauczycielek i nauczycieli stały się bardziej pozytywne, muszą jednak pokonać trudności w nauczaniu zdalnym, których obecnie doświadczają. W innym przypadku własną aktywność mogą łłumaczyć wyłącznie koniecznością wynikającą z zaistniałej sytuacji.

Analiza związku pomiędzy wybranymi aspektami funkcjonowania zawodowego nauczycielek i nauczycieli a postawami wobec kształcenia na odległość wykazała, że staż pracy nie różnicuje ich postaw. Najbardziej różnicuje je rodzaj szkół, w których są zatrudnieni badani - wyraźnie negatywnie wyróżnia się obraz sytuacji zarysowany przez nauczycieli szkół specjalnych. Już samo nauczanie $\mathrm{w}$ grupach silnie zróżnicowanych $\mathrm{w}$ aspekcie możliwości i potrzeb uczniów jest dla nauczycieli dużym wyzwaniem. Efektywność tego procesu zależy od dostosowania kształcenia do zróżnicowanych potrzeb i wymaga stosowania elastycznych rozwiązań oraz indywidualizacji pracy. Uczniowie z niepełnosprawnościami wymagają niejednokrotnie intensywnego, bezpośredniego nauczania niektórych umiejętności ${ }^{13}$, co może być szczególnie trudne podczas edukacji na odległość. Przeprowadzanie lekcji tematycznych online dla grup o zróżnicowanych potrzebach edukacyjnych może być więc dużym wyzwaniem, a brak osobistego kontaktu, który jest podstawą pracy w takich grupach, z pewnością rzutuje na codzienność kształcenia na odległość w szkołach specjalnych. Istnieje potrzeba objęcia szczegółowymi badaniami nauczycieli i nauczycielek tych szkół.

Skupianie się w dyskursie na temat kształcenia na odległość na problemach organizacyjnych, technicznych i na ocenianiu szkolnym jest ważne, bo to realne troski nauczycielki, dyrektorów szkół, rodziców i uczniów. Nie powinno jednak przysłaniać innych istotnych wątków, jak nowe wymiary wykluczenia (związane nie tyle z dostępem do Internetu czy komputera, co z utratą wychowawczego i opiekuńczego wsparcia szkoły) ${ }^{14}$, czy takich pozy-

${ }^{12}$ E.W. Aronson, T.D. Wilson, R.M. Akert, Psychologia spoteczna, s. 333.

${ }^{13}$ G. Szumski, Zróżnicowane grupy uczniów - jakie problemy? [w:] Edukacja włączająca w przedszkolu i szkole, red. I. Chrzanowska, G. Szumowski, Warszawa 2019.

${ }^{14}$ P. Plichta, Różne konteksty nierówności cyfrowych a wyzwania dla zdalnej edukacji - propozycje rozwiazań, [w:] Edukacja w czasach pandemii wirusa COVID-19. Z dystansem o tym, co robimy 
tywnych aspektów, jak nabywanie przez uczniów i nauczycieli nowych kompetencji, wzmacnianie więzi, czy wykorzystanie potencjału nowej sytuacji do budowania relacji ${ }^{15}$.

\section{Ograniczenia}

W celu wzmocnienia uzyskanych wniosków z części zależnościowej badań należy przeprowadzić badania na bardziej zróżnicowanej, ze względu na brane pod uwagę cechy, próbie.

\section{Podziękowania}

Dziękujemy osobom, które wzięły udział w badaniu.

\section{BIBLIOGRAFIA}

Aronson E.W., Wilson T.D., Akert R.M., Psychologia społeczna. Serce i umyst, Zysk i S-ka Wydawnictwo, Poznań 1997.

Badanie edukacji zdalnej w czasie pandemii, Centrum Cyfrowe, https://centrumcyfrowe.pl/ edukacja-zdalna/.

Bohner G., Wanke M., Postawy i zmiany postaw, Gdańskie Wydawnictwo Psychologiczne, Gdańsk 2004.

Buchner A., Majchrzak M., Wierzbicka M., Badanie edukacji zdalnej w czasie pandemii, https://centrumcyfrowe.pl/edukacja-zdalna/.

Czajkowska M., Postawy nauczycieli matematyki wobec zmian w edukacji, Społeczeństwo i Edukacja. Międzynarodowe Studia Humanistyczne, 2015, 3.

Jak wyglada nauczanie zdalne w naszych domach?' https://portal.librus.pl/rodzina/artykuly/nauczanie-zdalne-jak-wyglada-w-naszych-domach-pobierz-raport.

Jaskulska S., Ocenianie zachowania uczniów na stopień. Szkolna obsesja porządku w świetle matematycznej teorii chaosu, Podstawy Edukacji, 2015, 8.

Jaskulska S., Jankowiak B., Kształcenie na odległość w Polsce w czasie pandemii COVID-19 https://sites.google.com/view/ksztalcenie-pandemia-raport.

Kosiba G., Madejski E., Postawy nauczycieli wobec swej roli zawodowej w świetle wybranych koncepcji teoretycznych, Forum Oświatowe, 2014, 26(52).

Kossewska J., Uwarunkowania postaw: nauczyciele i inne grupy zawodowe wobec integracji szkolnej dzieci niepetnosprawnych, Wydawnictwo Naukowe Akademii Pedagogicznej, Kraków 2000.

Marody M., Sens teoretyczny a sens empiryczny pojęcia postawy analiza metodologiczna zasad doboru wskaźników w badaniach nad postawami, Państwowe Wydawnictwo Naukowe, Warszawa 1976.

Nawrocki R., Edukacja jako pole gry, [w:] Twierdza. Szkoła w metaforze militarnej. Co w zamian?, red. M. Dudzikowa, S. Jaskulska, Wolters Kluwer, Warszawa 2016.

obecnie jako nauczyciele, red. J. Pyżalski, Warszawa 2020, https://zdalnie.edu-akcja.pl/ [dostęp: 04.06.2020]; W. Poleszak, J. Pyżalski, Psychologiczna sytuacja dzieci i młodzieży w dobie epidemii, [w:] Tamże; M. Turczyk, S. Jaskulska, Kształcenie na odległość a prawa dziecka.

${ }^{15}$ J. Pyżalski, W. Poleszak, Relacje przede wszystkim - nawet jeśli obecnie jedynie zapośredniczone, [w:] Edukacja w czasach pandemii wirusa COVID-19. 
Plichta P., Różne konteksty nierówności cyfrowych a wyzwania dla zdalnej edukacji - propozycje rozwiąań, [w:] Edukacja w czasach pandemii wirusa COVID-19. Z dystansem o tym, co robimy obecnie jako nauczyciele, red. J. Pyżalski, EduAkcja, Warszawa 2020, https:/ / zdalnie. edu-akcja.pl/.

Poleszak W., Pyżalski J., Psychologiczna sytuacja dzieci i młodzieży w dobie epidemii, [w:] Edukacja w czasach pandemii wirusa COVID-19. Z dystansem o tym, co robimy obecnie jako nauczyciele, red. J. Pyżalski, EduAkcja, Warszawa 2020, https://zdalnie.edu-akcja.pl/.

Pyżalski J. (red.), Edukacja w czasach pandemii wirusa COVID-19. Z dystansem o tym, co robimy obecnie jako nauczyciele, EduAkcja, Warszawa 2020, https:/ / zdalnie.edu-akcja.pl/.

Pyżalski J., Poleszak W., Relacje przede wszystkim - nawet jeśli obecnie jedynie zapośredniczone, [w:] Edukacja w czasach pandemii wirusa COVID-19. Z dystansem o tym, co robimy obecnie jako nauczyciele, red. J. Pyżalski, EduAkcja, Warszawa 2020, https:/ / zdalnie.edu-akcja. $\mathrm{pl} /$.

Ratajczak P., Postawy nauczycieli wobec niezdyscyplinowania uczniów, Studia Edukacyjne, 2015,34 .

Rozporządzenie Ministra Edukacji Narodowej z 14 lutego 2017 r. w sprawie podstawy programowej wychowania przedszkolnego oraz podstawy programowej kształcenia ogólnego dla szkoły podstawowej, w tym dla uczniów z niepełnosprawnością intelektualną w stopniu umiarkowanym lub znacznym, kształcenia ogólnego dla branżowej szkoły I stopnia, kształcenia ogólnego dla szkoły specjalnej przysposabiającej do pracy oraz kształcenia ogólnego dla szkoły policealnej, DzU z 2017 r., poz. 356.

Skura M., Postawy nauczycieli szkoły specjalnej wobec osób z niepetnosprawnościa, Szkoła Specjalna, 2015, 1.

Szumski G., Zróżnicowane grupy uczniów - jakie problemy? [w:] Edukacja włączająca w przedszkolu i szkole, red. I. Chrzanowska, G. Szumowski, Wydawnictwo FRSE, Warszawa 2019.

Turczyk M., Jaskulska S., Kształcenie na odległość a prawa dziecka - nowe wymiary szkolnej ekskluzji w czasach epidemii COVID-19, Edukacja Elementarna w Teorii i Praktyce, 2020 (w druku).

Ustawa z 14 grudnia 2016 r. Prawo oświatowe (DzU 2020 poz. 374) oraz akty wykonawcze do ustawy.

Żytko M., Edukacja w ramionach standaryzacji - czy autonomia jest jeszcze możliwa? Czas Kultury, 2020, 1 . 